\title{
Narratives and the semiotic freedom of children
}

\section{Sara Lenninger ${ }^{1}$}

\begin{abstract}
Both adults' habits-of-thought and their understanding of children's stories shape how adults interpret children's participation in conversations. In the light of the requests on children's rights that follow from the Convention on the Rights of the Child (CRC) this paper stresses the relevance of authorities having semiotically informed knowledge on children's meaning-making within conversations with adults. In Article 12, the CRC stipulates the right of children to participate in and to be heard about decisions that affect their everyday lives. According to the same Article, however, these rights can be restrained, based on the authority's judgements of the child's age and maturity. Sociological studies have highlighted the importance of adopting the child's perspective in judging matters that concern her. The present paper further suggests that narrow conceptualization of the sign can help one to observe different levels of meaning in adults' and children's conversations better. Although Paul Ricœur did not investigate children's narratives per se, his theory of narratives and narrativity offers a phenomenological approach to development that allows for better theoretical discriminations of narrative as a semiotic resource, and can thus assist adults in truly listening to children.
\end{abstract}

Keywords: Convention on the Rights of the Child; semiotic freedom; narrativity; conversation; fiction; narrative traditions

\section{Introduction}

To understand what others mean, and to be understood in turn, is critical to influencing the decisions that affect people and to giving a person a sense of empowerment. This is particularly important when it is ultimately others who make the decisions, as is often the case in decisions concerning children - decisions concerning their health, education and living arrangements, among others. Joint understanding between decision-makers and decision-takers is a prerequisite to making decisions that recognize the best interests of those involved. This paper addresses a number of dilemmas arising from the 1989 UN Convention on the Rights of the Child (CRC). Children in some situations - such as migrant children

1 Faculty of Education, Kristianstad University, Kristianstad, Sweden; e-mail: sara.lenninger@ hkr.se. 
(SOU 2016:19: $170^{2}$ ), children with impairments, or children who are exposed to or witness violence in their home environment - are deemed to be especially vulnerable (Ponnert 2016). Therefore, their cases are given special consideration by social authorities. While the CRC adjudges rights to all children, and takes cognizance of the extra vulnerability of some of them, it is nevertheless open to interpretations with regard to how far these rights are to be extended and to whom. The discussion in this paper is based on the premise that the CRC applies to all children. The research on young children's meaning-making that is being addressed here in the framework of semiotic and cognitive-semiotic studies makes general claims on meaning-making and thus applies to every child, including children living under special circumstances. When practitioners meet a particularly vulnerable child, they also meet a child who is like other children in terms of having to deal with (being soaked in) an adult culture of meaning-making and taken-for-granted levels of meaning.

Article 12 of the CRC guarantees the right of children to be heard by authorities in all decisions concerning them. The child's right to freedom of expression is stated in Article 13 as the opportunity to seek and receive information and share ideas of all kinds. Together, these two articles stress the importance of respect for the child's opinions and (especially in Article 12) letting the child know that she is being heard, i.e., that her opinions matter. According to Article 12: "States Parties shall assure to the child who is capable of forming his or her own views the right to express those views freely in all matters affecting the child, the views of the child being given due weight in accordance with the age and maturity of the child" (emphasis mine, S. L.). In effect, the Convention states that the child's personal testimony and assessment of a matter should be respected, and that at the same time the authorities are obligated to determine the child's ability to form opinions in relation to the space of participation to which they deem her entitled.

A challenge in practice is to interpret a child's world and experiences on her own terms, while the ultimate decision-makers are adults (Heintz, Rasmusson 2016). Where migrant children are concerned, this often means adults from another culture. Sociological studies (e.g., Heintz, Rasmusson 2016; Tiller 1991) have attempted to address this dilemma by making a distinction between, on the one hand, adults (researchers or authorities) remaining within an adult perspective while attempting to take on a "child's-eye" perspective; and, on the other hand, the possible outcome of the same adults to hear and give voice to children contributing their own perspectives (the child's perspective).

2 SOU 2016:19. Barnkonventionen blir svensk lag. Betänkande av Barnrättighetsutredningen. Stockholm: Statens offentliga utredningar. https://www.regeringen.se/rattsliga-dokument/ statens-offentliga-utredningar/2016/03/sou-201619/. 
Through its implementation handbook (Unicef 2007), the Convention draws attention to the need to adapt one's communication strategy to each child's circumstances and needs: technical aids may be required in the event of disability, translators and interpreters where there are language barriers (Unicef 2007: 160). What the handbook fails to address, however, is the responsibility of authorities to educate themselves on the child's perspective. Contrast this with the possibility, widely discussed in the sociological literature on children, of not just hearing but also adopting the child's perspective in order to come to a better understanding of her meaning-making (e.g., James, Prout 1997; Rasmusson 1998; Sommer, Pramling-Samuelsson, Hundeide, 2010; Estola et al. 2010). To facilitate communication and prompt all children to engage in conversation, familiar objects, game play and storytelling can be used (Ahn, Filipenko 2007; Danby, Ewing, Thorpe. 2011; Ilgaz, Aksu-Koç 2005; Viljamaa 2010). This paper adds one more item to that list: background knowledge based on semiotically informed research on young children's meaning-making. The implication is that, in the light of the requirements of the CRC, combining studies in semiotic development and thorough semiotic research on communicative resources may bring forth new critical perspectives.

As a semiotician drawing on Paul Ricœur's view on narratives and the way a person experiences change and continuity over time, I would highlight how stories - the unfolding presentation of narratives - provide communicative situations where different, overlapping selves exist simultaneously. Sandy Farquhar (2010: 64) points out how narratives open up opportunities for an adult educator to approach a child's perspective by recognizing a "small window of opportunity" where two worlds - those of an adult and a child - may coexist while remaining separated. It is crucial to successful pedagogy that the educator should understand her own and others' meaning-making within a narrative structure in which realism and fiction interact on several semiotic levels. This is also true for the social worker who makes decisions that affect children's lives.

A central inquiry into children's semiotic development concerns the differentiation of signs and sign meanings from other instances or modes of meaning (see Bruner 1966:4 ff; 1990: 78-79; e.g. Piaget 1945: 68 ff.; e.g. Vygotsky 2012: 6-8, 87, 225). Sign meanings are a special category of meanings when it comes to how to interpret them. It follows that not all meanings are interpreted as sign meanings.

The sign concept is central to semiotic studies of all kinds, although there are different definitions and ways of applying it (Van Heusden 2004). In the phenomenological tradition, signs should be linked to a way of relating the perceiver to her contextual meanings. For the purposes of this paper, I prefer to adhere to a narrow sense of the sign by which sign meanings must involve reference. Signs 
(in this narrow sense) evoke interpretations and direct the perceiver's thoughts to what is only indirectly perceived in the sign's expression. They are consciously accessible (and thus can be operated on), although most often are not in focus (for a definition see Sonesson, Lenninger 2015: 193). Observe that the prerequisite of reference does not imply the requirement - or expectation - of a stable one-to-one relationship to an object of reference, nor that the object in question should exist in the "physical" world. The definition only demands that reference is implied from the point of view of an interlocutor. A reference meaning may very well change across a dialogue. What is central for this paper, however, is that the perception of there being a reference meaning at all may differ between the participants in a conversation.

Indeed, a great deal of people's meaning-making does not rely on sign meanings in this sense but is perceived as a more immediate experience of "beingnow-and-here". This is close to James Gibson's (1980: xii; 1979: 283) distinction between affordances and referential meanings. The distinction between signs and other meanings is not a straightforward one, though: no sharp line can be drawn where sign meanings stop and other meanings begin. Nevertheless, the experience of a meaning distinction in itself creates a difference in meaning. The consequent flexibility - or ambiguity - in creation and perception of meaning opens up possibilities both for communication and miscommunication.

The concept of semiotic freedom helps to clarify important differences between the conditions for meaning-making among children and adults. In this context, semiotic freedom is the ability to perceive and deploy different types and levels of meaning in communication (cf. Bruni 2008; Hoffmeyer 2010). The scope of one's semiotic freedom affects one's perception of signs and the ability to interpret, choose, and deploy different means of expression in a communicative situation. All in all, it regulates one's ability to navigate in, and have an effect upon, one's social and communicative environment. Differences in the interlocutor's development of semiotic freedom affect the outcome of the conversation - from both participants' points of view. This becomes all the more critical when adults use familiar objects, pictures, game play and stories in conversations with children. Those whose professional role is to listen to children and engage in conversation with them must cultivate a special knowledge of, and sensitivity to, children's accounts.

My focus here is on conversations with pre-schoolers: more precisely, on children's narratives and adults' understanding of those narratives. Children in the age group 2-5 years often and gladly engage in storytelling, drawing and play (Cremin et al. 2018). Together, the adult's habits-of-thought and understanding of the child's story shape the adult's interpretation of the child's participation in conversation. The resulting communications all fall along the spectrum of sign-meaning 
use whereby one understands the different levels of meaning implied in conversation. Studies on children's meaning-making (e.g. Bruner 1966: 30ff.; DeLoache 2004; DeLoache, Burns 1994; Liben 1999; Piaget 1945; 1947: 142 ff.; e.g. Vygotsky 2012: 103-154) have shown that children do not perceive signs in the same way as adults.

Early studies on young children's production and understanding of stories focused on investigating links between narrativity on the one hand and literacy and language development on the other hand (Siva, Strasser, Cain et al. 2014), along with how early-childhood narratives influence long-term school success (McCabe, Bliss 2003: 20-22; Nicolopoulou 2005). Other, associated studies have connected narrativity to play (Nicolopoulou et al. 2015) by observing play as the "story in action" (Paley 1990: 4). Generally, the emphasis is on play as a semiotic arena that facilitates children's plot construction in alignment with verbal narration where the story is told through play (Ilgaz, Aksu-Koç 2005), in particular, pretend play (Nicolopoulou, Ilgaz 2013). Sociocultural studies have provided enhanced dialogue strategies and improved everyday communication with parents and children by addressing the importance of shared meaning and the scaffolding of autobiographical references in narratives (Nelson, Fivush 2004; Faulkner 2017). Semiotic perspectives on meaning-making can be seen throughout studies on children's use of different communicative modes - including their fine-grained deployment of gaze, body posture, action and tone of voice (Cremin et al. 2018), along with their use of narrative prompting during toy play (Ilgaz, Aksu-Koç 2005). Indeed, the integration of different communicative means - such as gestures, language and pictures (or toys) - in a conversation to build up a composite whole is suggested to be a typical feature of human communication more generally (Zlatev 2019). From a semiotically informed perspective this combination of deploying different resources for meaning-making has been observed as a polysemiotic quality in human communication in general and in narratives specifically (Zlatev 2019; Zlatev, Zywiczynski, Wacewic 2020).

This paper highlights the importance of learning about children's narratives found in conversations or other communicative interactions with adults. Moreover, it considers the semiotic complexity of dealing with sign meanings and other levels of meanings in communicative situations. In doing so, it explores the levels of interpretations along an axis of fiction, history and reality-here-and-now from the point of view of the participants, individually. This can be described as having a fiction mode, a history mode or a reality mode in one's perception of "an utterance" in a complex communicative situation.

Ricœur (1998[1981]: 274) suggests a theoretical structure for understanding narrative that expressly addresses its semiotic levels of realism and fiction. 
Distinctions in meaning, of realism and fictiveness, are often taken for granted in strictly adult interactions. Ricœur discerns two narrative types - story and history, both with two levels of meaning: sense and reference. His concern is neither with the ontogeny of narrativity nor with adult/child narrative interactions specifically. Nevertheless, his structural, sociocultural, phenomenological approach attendant on the human perception of time as well as cultural narrative traditions - provides a theoretical framework to discuss opportunities and dilemmas presented by child/adult interactions.

\section{Semiotic freedom, narratives and habits-of-thought}

Semiotics and cognitive semiotics are tasked with exploring meaning-making through communication and the means by which it is achieved. Through (cognitive) semiotic investigation, oral storytelling becomes a form of meaning-making that, for example, partly overlaps with written (short stories, anthologies, novels) and pictorial stories (theatre, film), along with storytelling that actively blends the two (e.g. comics).

Taking an actively phenomenological approach, as cognitive semiotics does, adds subjectivity and intersubjectivity to the study of meaning-making. Cognitive semiotics offers ideal tools for studying children's meaning-making while examining how children's narratives both resemble and deviate from those of adults.

As noted above, while much interpersonal communication relies on sign meanings - through spoken and written language, pictures and gestures - a great deal of meaning-making does not depend on sign relations. A significant part consists in perceiving and acting in one's social and physical environment in the hereand-now, unmediated by signs in the narrow sense deployed here. Indeed, caught up within their lived world, people often take for granted that they can and $d o$ separate meanings communicated by signs from other sorts of meaning.

Although sign meanings are a special sort of meaning, many if not most things can become signs: i.e., take part in a sign relation. What determines if something is a sign is how it is perceived. One and the same expression can be a sign for one perceiver and not for another, even in the context of the same conversation: consider an audience member who does not understand what is happening on stage and rushes forward to try to stop the "king's" murder! Consider also the situation when it is unclear for the perceiver if a yawn or a grunt from the narrator is part of enacting the story or was produced for other reasons.

The concept of the lifeworld (Lebenswelt) comes from Edmund Husserl (18591938), who describes the world-as-experienced wherein human expectations of 
regularity create the expectation of a world reflecting that regularity (Sonesson 1989: 30ff.). Habits are the "sedimented" effects of the past (past actions and expectations) within the present (Crossley 2001: 116), formed by the process of one's being-in-the-world. In the lifeworld, the sun always goes up in the morning; water makes one wet; people communicate: these things are taken for granted.

Through ongoing experience of the lifeworld, people adjust their expectations, learn new things, and change their routines. The lifeworld is a realm of constant expectations, of taken-for-granted assumptions governing one's interactions with and communications in it. In the lifeworld, sign meanings are not considered to be on the same level of reality as the rest of the world. They are meanings created to communicate about the world. They take a step back from the world to talk about it. Much of people's meaning-making is an attempt to adapt to and navigate through the world in which they find themselves.

What more can be said about the sign? A sign expression typically does not reveal all that it represents. A sign has properties that do not relate to the represented meaning - and should not be understood so - but rather refer to the sign itself and the way it is expressed. Typical, too, is that the meaning in sign relations is asymmetric: something is evaluated as an expression for something else and not vice versa (Sonesson 2010; Sonesson, Lenninger 2015), at least not without radically changing the meaning. The separation of the signifier from the signified from the point of view of its perceiver - the differentiation of the sign (Piaget 1945: 293, 1947: 148-149; Sonesson 1989: 95) - is an essential feature in developing cognizant understanding of sign communication. The differentiation of the sign is both a creative source of possibilities and a stumbling block for younger children.

In studying children's cognitive development, Piaget (1945) recognizes an important difference between sensorimotor meaning: more basic meaning, constrained by here-and-now praxis, perception, and movements; and sign use: higher level, more abstract representational meaning. For Piaget, sign use, to which he designates the symbolic function (Piaget 1945: 6-7, 292) - later on, the semiotic function (Piaget, Inhelder 1966: 41) - is the manifestation of a cognitive function that develops from around the age of 18 months. As children begin to understand and control their use of sign relations, they undergo a fundamental structural change in their thinking and communication. Communicative development begins with sensorimotor meaning-making from earliest infancy and only culminates in the ability to differentiate and use signs fully by the early teenage years. One of the consequences is that a great deal of communication - involving a great variety and complexity of meaning-making - precedes and accompanies the more developed, more expressly self-conscious use of signs. 
Piaget made no specific study of changes or development in adult communication. Consequently, he did not study how adults adapt their communication when communicating with children; neither did he consider how sign use and conscious awareness of sign relations develop in adulthood, beyond the early teenage years.

Responding to Piaget's (1930[1923]) theories of cognitive development, Lev Vygotsky (1896-1934) wrote that an individual's development of semiotic abilities must always be considered part of a dialectic relationship to the surrounding culture (Vygotsky, 1978: 27-30, 2012: 133). He describes a structural change in children's cognition as they come closer to adults' more experienced understanding of word meaning and concept formation. He, too, sets forth stages of cognitive development. While Piaget stops his account at the early teenage years Vygotsky (1978) describes a continuing development through adulthood: a life-long process of learning, development, and refinement, particularly of one's use and understanding of language.

Meaning develops and enriches itself through communication. Meaning becomes real to an individual through her lived experience of adapting to, and participating directly in, her physical, social, and emotional environments (e.g. Nelson 2007: 17) - but this can also occur second hand, through the use of signs (Gibson 1979: 273; Ricœur 1998[1981]). People communicate with each other and themselves - as sign users. Communication shapes its participants at the same time as it reflects them: awareness of the ability to influence and grow in governance of expression and content varies from one individual to another. Some of that variation may be due to differences in domain expertise: a surgeon, usually, is not a philosopher or a linguist. Some may be due to differences in the habit of using one means of expression versus another: e.g., speaking versus writing. Some may be linked to situational factors like power relations: an employee may never learn to challenge a boss she seldom encounters. The variation in interpretation of an utterance spells out the differences between what is overtly said or otherwise presented - through pictures, gestures, or body language and the repertoire of possible interpretations of that communication. Two concepts that are useful in this context are the aforementioned semiotic freedom and the closely related concept of metacognition.

As noted above, semiotic freedom concerns the ability to perceive and deploy different types of semiotic meaning-making in responding and adapting to one's physical, social, and emotional environments, as through spoken communication. It offers the ability to navigate - and make an impact on - those environments.

Together with their colleagues, Piaget (1930[1923], 1945, 1947), Vygotsky $(1978,2012)$, and Bruner $(1966,1986)$ did ground-breaking research in developmental psychology on the emergence of semiotic freedom in children. Setting 
aside the differences that have already partly been commented upon in this paper, what their research had in common was their goal to study the development of semiotic abilities by drawing attention to children's understanding and use of such communicative resources as language, pictures, body language and other modes of expression - both those used by the children themselves and those used by others in their proximity.

The term metacognition is used in many, albeit related, ways; broadly speaking, it can be understood as thinking about (perceiving in thought) one's own or others' thinking (Brown, A. 1987; Bråten 1991; Flavell 2000; Perner 1991). In the context of this paper, metacognition concerns self-awareness of semiotic means, notably fully-fledged signs (Piaget 1945, 1947): one reflects on how best to express something (in a picture, the words of a story, or a combination of the two) or on what someone else is expressing (how they are expressing it and why). The ability to metacognize is linked to an individual's degree (or scope) of semiotic freedom that in turn is a concept that relates to the possibility of mastering semiotic complexity in communication. Equally important, flexibility in metacognition affects both the individual's and the group's ability to understand others' intent within a communicative context. A topical example is the competence (or incompetence) of authorities to understand a young child's perspective - for example, that of a three-year-old - as she describes her life situation and experiences.

Every child is born into a communicative environment, deeply ingrained with language, other means of meaning-making and sheer habit. People talk about and often narrate on everyday and less-than-everyday matters and events. Adults are prepared to incorporate newborns into their culture. It is well known and has been studied long, that people adapt their communication style to young children (see, e.g., Bates et al. 1979; Rodríguez et al. 2015; Cremin et al. 2018; Nelson 2010). Through bodily contact, gesture, glances, body language, spoken words, and other sounds, infants are quickly acculturated into the communicative milieu. Moreover, research on adult/infant interaction has clearly shown that it is not only adults and older children who drive the communication forward; the very youngest of newborns actively communicate with others (Trevarthen 2015; Trevarthen, Aitken 2001).

Of course, active communication is no guarantee that all participants perceive that communication in the same way. The partaking in communicative interactions that I have described elsewhere as communication games (Lenninger 2012: 129ff.; cf. "naming games", Bates et al. 1979: 38-42) often antedates the full understanding of semiotic levels implied in the communicative situation. Already from early infancy, young children grasp, imitate and actively engage in the shaping of communicative rules together with their interlocutors (Nelson 2007; 2010). A 
recent study reported that children as young as six months of age notice being imitated; they respond with approaching behaviour and a smile (Sauciuc et al. 2020). Within the framework of communication games, interlocutors form expectations and habits through their use of pictures and narratives - children's anticipation of which (in context) precedes their perception, never mind mastery, of signs. True semiotic freedom, on the other hand, presupposes such familiarity.

A communicative situation in which all participants perceive exactly the same content is never a starting point for communication, nor is it an obvious longterm goal (Lotman 2009: 4-6). It simply does not happen. Increased semiotic freedom, on the other hand, is a worthy goal: a better understanding of and comfort with sign use helps one's ability to engage in dialogue. Blending meaning relations with creative sign use improves communication skills for the habitual sign user, at the same time it is critical for professionals attempting to understand children's conversations from the child's point of view.

\section{Narrated worlds}

As Ricœur observes, the only way to tell about oneself - the only way to make one's experiences heard - is through narrative:

The historicity of human experience can be brought to language only as narrativity, and moreover that this narrativity itself can be articulated only by the crossed interplay of the two narrative modes. For historicity comes to language only so far as we tell stories or tell history. In a word, if our historical condition requires nothing less than the conjunction of two narrative genres, it is because of the very nature of our experience of being historical. (Ricœur 1998[1981]: 294)

Narrative traditions derive from at least two types or dimensions of narrative: history (empirical narratives, sedimented in experience) and story (fiction, sedimented in narrativity itself). Even the fictive narrative in some way complies with experience; however, even in historical narrative, the original (subjective!) experience is separate from its narrative expression. The original "has lost its specificity in order to conform with a general concept of event, itself deprived of any particular relation to the act of narrating" (Ricœur 1998[1981]: 276).

Ricœur suggests that history and fiction are closely related, with similar design features, even as they make different claims on reality. Semiotic ambiguities/complexities are ingrained in the very constituent structure of narratives. Put it in another way, Ricœur argues that, on the expression side, history and story are similarly structured while differing along the axes of fiction and realism. 
In Ricœur's view, narratives truly are signs in the narrow sense I am using. Each narrative refers to events - historical or imaginary - perceived as separated in time and space from the act of narrating itself. The same event can be told in various ways, focusing on different aspects of the event. There need be no sharp line between fictional representation of reality (as perhaps in fairy tales) and historically sanctioned fiction - indeed, there probably cannot be. Retelling a historical event may draw on fictive elements, yet narrate a real event, while even the most fantastical fiction succeeds because of the semblance it retains to recognizable reality. Of course, a lot can be said about the ontology of reality and fiction. My interest here lies in the perception of different levels or dimensions of reality in narratives. For Ricœur (1998[1981]: 278), plot is the underlying narrative structure - across all narrative forms - that bridges the gulf between historical and fictional narrative, while emplotment is the act of bringing the various plot elements together.

The plot is simply the event set in a narrative context; it comes with its own distinct semiotic complexity. It reveals the narratives at the level of manifestation: how the narrative is expressed (choice of words, choice of pictures) as shaped by hidden layers of historical and cultural interpretation, as well as the narrative genre itself. Plot has (at least) two constituents (Ricœur 1998[1981]: 277-279, 1984[1983]: 67): sequence and configuration. Sequence is episodic, manifested by the chronological presentation of events (as possibly experienced in real life). Configuration is non-chronological, enriching the narrative context with protagonists' roles and other features.

Stories are a rich semiotic resource. They are a way of creating meaningful content that presupposes some degree of semiotic freedom. Therefore, to choose the form of a story is to employ a rich semiotic resource for narration with many opportunities for creative meaning-making. In adult culture, where sign relations can be unclear but still assumed and understood because of well-ingrained habits, the links between story world and lived world - often far from straightforward are important aspects of how stories are interpreted. The appropriate degree of realism makes a story comprehensible as a description of lived events (possible or actual) or as fantasy. With a realistic backdrop, a fictive world becomes believable: i.e., it becomes good fiction.

The inverse relation is also common, especially in stories for children: a fictive world can be used to talk about possible or actual lived events. In stories, rabbits can hold tea parties or a group of dogs set out jointly to create a new life for themselves as they flee across the sea. The boundary where fantasy stops and reality begins need not be sharp but can be - must be - flexibly negotiated within the framework of the story. The overt identification of narrative as the form of 
expression shapes how statements in the story, and the story as a whole, are understood.

As noted earlier, children engage in communicative interactions since infancy: they are primed for it. Narratives are widely understood to be among the "human universals" (Brown, D. 1991: 132); they fulfil a vital role in human teaching and cultural learning (Scalise, Sugiyama 2017). Bruner (1991: 2-3) writes that narratives belong among the "cultural toolkits" that operate as instruments of the mind. Through daily rituals at home, at preschool, together with their elders, very young children are introduced to the common stories of a culture. It should come as no surprise that children actively participate in the telling and retelling of stories from a similarly early age (Ilgaz, Aksu-Koç 2005). Studies have shown that preschool children distinguish the world of imagination from the world of here-and-now even as the boundary between those worlds is neither clear nor stable (e.g., Ahn, Filipenko 2007; Corriveau, Chen, Harris 2014; Harris et al. 1991). They are able to perceive meanings within the framework of a story without that story needing to be conveyed as a picture of reality outside the story itself (DeLoache, Burns 1994; Lenninger 2012; Robinson, Nye, Thomas 1994).

Young children tend to have an easier time perceiving visual similarity between one image and another (e.g., recognizing the same object across several images) than perceiving the similarity between an image and the depicted object (Lenninger 2009). That suggests that the meaning of an image applies to the image, and the meaning of a story works in the context of the story, independently of connections to "external" reality. Adults need to take this into account in interpreting children's stories if they are to understand correctly the children's understanding of various kinds of meaning. That places a high demand on adults' capacity for and awareness of metacognition.

Narrativity is interwoven with cultural norms concerning what is worth telling, how one may tell it, and who is expected to do the telling (McCabe, Bliss 2003: 23; Sinha 2009). From an early age, children are invited to participate in storytelling. They are challenged daily in a continuously iterative process that introduces them to their culture's spoken and unspoken rules.

When a new culture is encountered, the consequent challenge to (and, often, threatened collapse of) current norms is a problem for everyone, adults as well as children; but children are confronted by the challenges of sign use in navigating these cultural clashes more than adults. Clashes can arise in various kinds of cultural encounters, including ones that adults might find mundane: as when children meet figures of authority in a new context, without otherwise stepping outside the sociolinguistic context of their everyday lives. That might be a visit from social services or a trip to a healthcare clinic. In these situations, all young 
children face challenges in conducting conversations on adult terms, and some children who want to tell their story face the extra challenges of a new language and new cultural norms about what is worth telling.

Although much remains to be done both in research and practice, authorities have - at least to some extent - risen to the challenges posed by linguistic diversity and cultural expectations. Policies derived from the CRC (Unicef 2007: $160,170)$ are aimed to protect the credibility of child/adult conversations, notably as regards migrant children. Unfortunately, little attention to date has been directed towards research and practice concerning young children's semiotic skills and adults' understanding of their meaning-making. This paper has attempted to make a start in that direction.

\section{Conclusion}

Stories are semiotic resources for meaning-making. Mastery of story production and understanding depends upon the understanding of signs in the representation of events, experiences, emotions, and so on. Such mastery is intimately linked to semiotic freedom. A story can take many forms and be presented in many ways: spoken or written language, a still picture or a series of pictures, stage drama or film. A story can present different levels of realism: it can depict actual or imagined experience, or a mixture of both. The imagined experience might be possible or (seemingly) impossible; but, to be (re-)told, it nevertheless must conform to a certain level of realism as well as standard conventions for narrativity. Although Ricœur does not investigate children's narratives per se, his narrative theory aligns well with a phenomenological approach to developmental subjectivity while facilitating the proper discrimination of narrative as a semiotic resource in adult/child interactions.

This article has attempted to highlight the critical difference that adequate knowledge of sign use - as a key component of communication - makes in conversations between preschool children and adults. Its central thesis is that, if one of the participants in a conversation (an adult) assumes a certain understanding of signs that another participant (a child) does not possess - because she does not perceive the relevant sign relations in the same way or at the same level then the participants will perceive the interaction differently without proper awareness of having done so. Two things are of key importance here. First, children's understanding of how narratives relate to experiences in the lived world are not necessarily consistent with what an adult takes for granted. Second, children often understand more than adults expect or realize. Children have a way 
of meaning-making that is, in many ways, distinct from that of adults. Further research into their distinctive modes of meaning-making is needed.

Today, the CRC has been ratified by virtually all countries of the world, with the exception of the USA (Urinboyev, Wickenberg, Leo 2016). It has the status of law in Finland, Norway and Sweden. Inspired by the CRC, research on adult/child interactions in the framework of professional authorities is finally being brought up to date. Demands can and must be placed - are being placed - on authorities and other decision-makers to address children's meaning-making more thoughtfully and honestly, while taking children's perspectives into consideration. That can only happen if the adults have the necessary tools to do so. The overarching goal of this article has been to draw attention to the relevance and, indeed, critical importance of better adult knowledge of children's meaning-making, in all its semiotic richness, especially in those areas where an individual child's participation is needed for making decisions that affect the child's living conditions and education. Such knowledge is an ethical obligation if children's right to participate in decisions that affect them is to be taken seriously. Responsibility lies with the authorities, their representatives in care, administration, and education, and society at large to understand and take on the child's perspective; it does not rest with the children to understand the nuances of adult-driven communication, with all its complexity of sign relations. The Convention on the Rights of the Child will accept no less.

Acknowledgements: I would like to thank both Dr. Joel Parthemore (University of Skövde) and Dr Lisbet Rausing for their considerate and helpful comments. I also thank the Department of Sociology of Law at Lund University for generously inviting me to collaborate with the Child Rights Institute through seminars and publications, from which the framework for this article was born.

\section{References}

Ahn, Jiryung; Filipenko, Margot 2007. Narrative, imaginary play, art and self: Intersecting worlds. Early Childhood Education Journal 34(4): 279-289. https://doi.org/10.1007/ s10643-006-0137-4

Bates, Elizabeth; Benigni, Laura; Bretherton, Inge; Camaioni, Luigia; Volterra, Virginia 1979. The Emergence of Symbols: Cognition and Communication in Infancy. New York: Academic Press.

Brown, Ann 1987. Metacognition, executive control, self-regulation, and other more mysterious mechanisms. In: Weinert, Franz E.; Kluwe, Rainer H. (eds.) Metacognition, Motivation, and Understanding. Hillsdale: Lawrence Erlbaum, 65-116. 
Brown, Donald E. 1991. Human Universals. New York: McGraw-Hill.

Bruner, Jerome (ed.) 1966. Studies in Cognitive Growth: A Collaboration at the Center for Cognitive Studies. New York: Wiley.

Bruner, Jerome 1986. Actual Minds, Possible Worlds. Cambridge: Harvard University Press. https://doi.org/10.4159/9780674029019

Bruner, Jerome 1990. Acts of Meaning. Cambridge: Harvard University Press.

Bruner, Jerome 1991. The narrative construction of reality. Critical Inquiry 18(1): 1-21. https://doi.org/10.1086/448619

Bruni, Luis 2008. Semiotic freedom: Emergence and teleology in biological and cognitive interfaces. American Journal of Semiotics 24(1-3): 57-73. https://doi.org/10.5840/ ajs2008241/35

Bråten, Ivar 1991. Vygotsky as precursor to metacognitive theory: I. The concept of metacognition and its roots. Scandinavian Journal of Educational Research 35(3): 179-192. https://doi.org/10.1080/0031383910350302

Corriveau, Kathleen H.; Chen, Eva E.; Harris, Paul L. 2014. Judgments about fact and fiction by children from religious and nonreligious backgrounds. Cognitive Science 39(2): 353-382. https://doi.org/10.1111/cogs.12138

Cremin, Teresa; Flewitt, Rosie; Swann, Joan; Faulkner, Dorothy; Kucirkova Natalia 2018. Storytelling and story-acting: Co-construction in action. Journal of Early Childhood Research 16(1): 3-17. https://doi.org/10.1177/1476718X17750205

Crossley, Nick 2001. The phenomenological habitus and its construction. Theory and Society 30(1): 81-120. https://doi.org/10.1023/A:1011070710987

DeLoache, Judy S. 2004. Becoming symbol-minded. Trends in Cognitive Sciences 8(2): 66-70. https://doi.org/10.1016/j.tics.2003.12.004

DeLoache, Judy S.; Burns, N. M. 1994. Early understanding of the representational function of pictures. Cognition 52(2): 83-110. https://doi.org/10.1016/0010-0277(94)90063-9

Danby, Susan; Ewing, Lynette; Thorpe, Karen 2011. The novice researcher: Interviewing young children. Qualitative Inquiry 17(1): 74-84. https://doi.org/10.1177/ 1077800410389754

Estola, Eila; Kontio, Marikaisa; Kyrönniemi-Kylmänen, Taina; Viljamaa, Elina 2010. Ethical insights and child research. In: Kronqvist, Eeva-Liisa; Hyvönen, Pirkko (eds.), Insights and Outlouds: Childhood Research in the North. Oulu: Oulu University Press, 185-201.

Farquhar, Sandy 2010. Ricoeur, Identity, and Early Childhood. Lanham: Rowman \& Littlefield.

Faulkner, Dorothy 2017. Young children as storytellers: Collective meaning making and sociocultural transmission. In: Cremin, Teresa; Flewitt, Rosie; Mardell, Ben; Swann, Joan. (eds.), Storytelling in Early Childhood: Language, Literacy, and Culture. London: Routledge, 85-100.

Flavell, John H. 2000. Development of children's knowledge about the mental world. International Journal of Behavioral Development 24(1): 15-23. https://doi.org/10. $1080 / 016502500383421$

Gibson, James 1979. The Ecological Approach to Visual Perception. Boston: Houghton Mifflin. 
Gibson, James 1980. Foreword: A prefatory essay on the perception of surfaces versus the perception of markings on a surface. In: Hagen, Margaret A. The Perception of Pictures. Vol. 1. Alberti's Window, the Projective Model of Pictorial Information. New York: Academic Press, xi-xviii.

Harris, Paul; Brown, Emma; Marriott, Crispin; Whittall, Semantha; Harmer, Sarah 1991. Monsters, ghosts and witches: Testing the limits of the fantasy - reality distinction in young children. Developmental Psychology, 9(1): 105-123. https://doi.org/10.1111/ j.2044-835X.1991.tb00865.x

Heintz, Maria; Rasmusson, Bodil 2016. Taking children's perspectives in qualitative research. In: Rasmusson, Bodil; Svensson, Kerstin (eds.), Researching Children's Perspectives When Norms and Values are in Conflict. Lund: Lund University Press, 16-24.

Hoffmeyer, Jesper 2010. Semiotic freedom: An emerging force. In: Davies, Paul; Gregersen, Niels Henrik (eds.), Information and the Nature of Reality: From Physics to Metaphysics. Cambridge: Cambridge University Press, 185-204. https://doi.org/10.1017/ CBO9780511778759.010

Ilgas, Hande; Aksu-Koç, Ayhan 2005. Episodic development in preschool children's playprompted and direct-elicited narratives. Cognitive Development 20(4): 526-544. https:// doi.org/10.1016/j.cogdev.2005.08.004

James, Allison; Prout, Alan (eds.) 1997. Constructing and Reconstructing Childhood: Contemporary Issues in the Sociological Study of Childhood. (2nd ed.) London: Falmer.

Lenninger, Sara 2009. In search of differentiations in the development of a picture sign. In: Tarasti, Eero (ed.), Communication: Understanding/Misunderstanding (Vol. 2). Proceedings of the 9th Congress of the IASS/AIS 2007. Helsinki: Acta Semiotica Fennica, 893-952.

Lenninger, Sara 2012. When Similarity Qualifies as a Sign: A Study in Picture Understanding and Semiotic Development in Young Children. (PhD thesis.) Lund: Lund University Press.

Liben, Lynn S. 1999. Developing an understanding of external spatial representation. In: Sigel, Irving E. (ed.), Development of Mental Representation: Theories and Applications. Mahwah: Erlbaum 297-321.

Lotman, Juri 2009. Culture and Explosion. (Clark, Wilma, trans.; Grishakova, Marina, ed.) Berlin: Mouton de Gruyter.

McCabe, Allyssa; Bliss, Lynn S. 2003. Patterns of Narrative Discourse. Boston: Allyn \& Bacon.

Nelson, Katherine 2007. Young Minds in Social Worlds: Experience, Meaning, and Memory. Cambridge: Harvard University Press. https://doi.org/10.4159/9780674041400

Nelson, Katherine 2010. Developmental narratives of the experiencing child. Child Development Perspectives 4(1): 42-47. https://doi.org/10.1111/j.1750-8606.2009.00116.x

Nelson, Katherine; Fivush, Robyn 2004. The emergence of autobiographical memory: A social cultural developmental theory. Psychological Review 111(2): 486-511. https://doi. org/10.1037/0033-295X.111.2.486

Nicolopoulou, Ageliki 2005. Play and narrative in the process of development: Commonalities, differences, and interrelations. Cognitive Development 20(4): 495-502. https://doi.org/10.1016/j.cogdev.2005.09.001 
Nicolopoulou, Ageliki; Schnabel Cortina, Kai; Ilgaz, Hande; Cates, Carolyn; de Sá, Aline B. 2015. Using a narrative- and play-based activity to promote low-income preschoolers' oral language, emergent literacy, and social competence. Early Childhood Research Quarterly 31: 147-162. https://doi.org/10.1016/j.ecresq.2015.01.006

Nicolopoulou, Ageliki; Ilgaz, Hande 2013. What do we know about pretend play and narrative development? American Journal of Play 6(1): 55-81.

Paley, Vivian G. 1990. The Boy Who Would Be a Helicopter: The Uses of Storytelling in the Classroom. Cambridge: Harvard University Press.

Perner, Josef 1991. Understanding the Representational Mind. Cambridge: The MIT Press. Piaget, Jean 1930[1923]. Le langage et la pensèe chez l'enfant. Neuchâtel-Paris: Delachaux \& Niestlé.

Piaget, Jean 1945. La formation du symbole chez l'enfant: imitation, jeu et rêve, image et représentation. Neuchâtel-Paris: Delachaux \& Niestlé.

Piaget, Jean 1947. La psychologie de l'intelligence. Paris: Colin.

Piaget, Jean; Inhelder, Bärbel 1966. La psychologie de l’enfant. (1. éd.) Paris: Presses universitaires de France.

Ponnert, Lina 2016. Article 3 and 12 in the Convention on the Rights of the Child: Some dilemmas and controversies in Swedish practice. In: Rasmusson, Bodil; Svensson, Kerstin (eds.), Researching Children's Perspectives When Norms and Values Are in Conflict. Lund: Lund University Press, 68-73.

Rasmusson, Bodil 1998. Stadsbarndom: Om barns vardag i en modern förort. (PhD thesis.) Lund: Lund University Press.

Ricœur, Paul 1984[1983]. Time and Narrative. Vol. 1. Chicago: The University of Chicago Press.

Ricœur, Paul 1998[1981]. Hermeneutics and the Human Sciences: Essays on Language, Action and Interpretation. (Thompson, John B., trans.) Cambridge: Cambridge University Press.

Robinson, Elizabeth J.; Nye, Rebecca; Thomas, Glyn V. 1994. Children's conceptions of the relationship between pictures and their referents. Cognitive Development 9(2): 165-191. https://doi.org/10.1016/0885-2014(94)90002-7

Rodríguez, Cintia; Moreno-Núñez, Ana; Basilio, Marisol; Sosa, Noelia 2015. Ostensive gestures come first: Their role in the beginning of shared reference. Cognitive Development 36: 142-149. https://doi.org/10.1016/j.cogdev.2015.09.005

Sauciuc, Gabriela-Alina; Zlakowska, Jagoda; Persson, Tomas; Lenninger, Sara; Alenkaer Madsen, Elainie 2020. Imitation recognition and its prosocial effects in 6-month old infants. Plos One 15(5): e0232717. https://doi.org/10.1371/journal.pone.0232717

Saussure, Ferdinand de 1968[1916]. Cours de linguistique generale. Paris: Payot.

Scalise Sugiyama, Michelle 2017. Oral storytelling as evidence of pedagogy in forager societies. Frontiers in Psychology 8(471). https://doi.org/10.3389/fpsyg.2017.00471

Sinha, Chris 2009. Objects in a storied world: Materiality, normativity, narrativity. Journal of Consciousness Studies 16(6-8): 167-190.

Siva, Macarena; Strasser, Katherine; Cain, Kate 2014. Early narrative skills in Chilean preschool: Questions scaffold the production of coherent narratives. Early Childhood Research Quarterly 29(2): 205-213. https://doi.org/10.1016/j.ecresq.2014.02.002 
Sommer, Dion; Pramling-Samuelsson, Ingrid; Hundeide, Karsten (eds.) 2010. Child Perspectives and Children's Perspectives in Theory and Practice. New York: Springer. https://doi.org/10.1007/978-90-481-3316-1

Sonesson, Göran 1989. Pictorial Concepts: Inquiries into the Semiotic Heritage and Its Relevance to the Interpretation of the Visual World. Lund: Lund University Press.

Sonesson, Göran 2010. Semiosis and the elusive final interpretant of understanding. Semiotica 179: 145-258. https://doi.org/10.1515/semi.2010.023

Sonesson, Göran; Lenninger, Sara 2015. The psychological development of semiotic competence: From the window to the movie by way of the mirror. Cognitive Development 36: 191-201. https://doi.org/10.1016/j.cogdev.2015.09.007

Tiller, Per Olav 1991. Barneperspektivet - om å se og bli sett. Vårt perspektiv på barn eller omvendt? [The child's perspective: On seeing and being seen. Our perspective on children, or the other way around?] In: Nytt fra forskning om barn i Norge 1. Trondheim: Norsk senter for barneforskning, 71-77.

Trevarthen, Colwyn 2015. Infant semiosis: The psycho-biology of action and shared experience from birth. Cognitive Development 36: 130-141. https://doi.org/10.1016/j. cogdev.2015.09.008

Trevarthen, Colwyn; Aitken, Kenneth J. 2001. Infant intersubjectivity: Research, theory and clinical applications. The Journal of Child Psychology and Psychiatry 42(1): 3-48. https://doi.org/10.1111/1469-7610.00701

Unicef 2007. The Implementation Handbook for the Convention on the Rights of the Child. (3rd ed.) UNICEF Regional Office for Europe, Geneva: Switzerland.

Urinboyev, Rustamjon; Wickenberg, Per; Leo, Ulf 2016. Child rights, classroom and school management: A systematic literature review. International Journal of Children's Rights 24: 522-547. https://doi.org/10.1163/15718182-02403002

Van Heusden, Barend 2004. A bandwith model of semiotic evolution. In: Bax, Marcel; Van Heusden, Barend; Wildgen, Wolfgang; Brandt, Per Aage (eds.). Semiotic Evolution and the Dynamics of Culture. Bern: Peter Lang, 3-33.

Viljamaa, Elina 2010. Block story: Listening to child's narrating at home. In: Kronqvist, Eeva-Liisa; Hyvönen, Pirkko (eds.), Insights and Outlouds: Childhood Research in the North. Oulu: Oulu University Press, 173-184.

Vygotsky, Lev S. 2012. Thought and Language. (Revised and expanded ed.; Hanfmann, Eugina, trans.; Vakar, Gertruda; Kozulin, Alex, eds.). Cambridge: The MIT Press.

Vygotsky, Lev S 1978. Mind in Society: The Development of Higher Psychological Processes. (Cole Míchael, trans.; John-Steiner, Vera; Scribner, Sylvia; Souberman, Ellen, eds.) Cambridge: Harvard University Press.

Zlatev, Jordan 2019. Mimesis theory, learning, and polysemiotic communication. In: Peters, Michael Adrian (ed.), Encyclopedia of Educational Philosophy and Theory. Singapore: Springer Nature Singapore Pte Ltd. https://doi.org/10.1007/978-981-287532-7_672-1

Zlatev, Jordan; Zywiczynski, Przemyslaw; Wacewic, Slawomir 2020. Pantomime as the original human-specific communicative system. Journal of Language Evolution 2020: 


\section{Нарративы и семиотическая свобода детей}

Как привычки мышления взрослых, так и их понимание детских рассказов формирует то, как взрослые интерпретируют участие детей в разговорах. В контексте Конвенции о правах ребенка в настоящем исследовании подчеркивается важность того, чтобы облеченные властью взрослые понимали, каким образом дети конструируют значения в разговорах со взрослыми. ООН устанавливает право детей участвовать в принятии решений, затрагивающих их повседневную жизнь, их право быть услышанными. Однако, согласно той же статье, эти права могут быть ограничены в зависимости от решений властей в отношении возраста и степени зрелости ребенка. Социологические исследования подчеркивают важность учета мнения ребенка при решении затрагивающих его вопросов. В статье указывается, что узкая интерпретация знаков может способствовать лучшему различению разных уровней значения в разговорах взрослых с детьми. Несмотря на то, что Пол Рикер не изучал рассказы детей per se, его нарративная теория предлагает феноменологический подход, который позволяет лучше теоретически исследовать нарратив как семиотический ресурс и, таким образом, может помочь взрослым по-настоящему понимать детей.

\section{Narratiivid ja laste semiootiline vabadus}

Nii täiskasvanute mõtteharjumused kui ka see, kuidas nad laste lugusid mõistavad, kujundavad seda, kuidas täiskasvanud tõlgendavad laste osalemist vestlustes. Arvestades laste õigusi puudutavaid nõudmisi, mis tulenevad ÜRO lapse õiguste konventsioonist, rõhutatakse artiklis, kui oluline on, et ametivõimudel oleksid semiootiliselt informeeritud teadmised laste tähendusloomest vestlustes täiskasvanutega. Konventsiooniga nõutakse lastele õigust osaleda oma igapäevaelu puudutavate otsuste langetamises ning end nende osas kuuldavaks teha. Ent sellesama artikli kohaselt võib neid õigusi piirata, lähtudes võimuesindajate poolt lapse vanusele ja küpsusele antavast hinnangust. Sotsioloogilistes uurimustes on toodud esile, kui tähtis on last puudutavates küsimustes otsuste langetamisel võtta omaks lapse perspektiiv. Käesolevas artiklis osutatakse järgnevalt, et märgi kitsas tõlgendamine võib aidata paremini märgata täiskasvanute ja laste vestluste erinevaid tähendustasandeid. Kuigi Paul Ricoeur ei uurinud laste narratiive per se, pakub tema narratiivide ja narratiivsuse teooria välja fenomenoloogilise lähenemise arengule, mis võimaldab teoreetiliselt paremini eristada narratiivi semiootilise ressursina ning seega aidata täiskasvanutel lapsi tõepoolest kuulda võtta. 